2015

\title{
Where Have all the Patent Lawyers Gone? Long Time Passing...
}

Kenneth L. Port

Mitchell Hamline School of Law, ken.port@mitchellhamline.edu

Molly R. Littman

Lucas Hjelle

Publication Information

97 Journal of the Patent and Trademark Office Society 193 (2015)

\section{Repository Citation}

Port, Kenneth L.; Littman, Molly R.; and Hjelle, Lucas, "Where Have all the Patent Lawyers Gone? Long Time Passing..." (2015). Faculty Scholarship. Paper 267.

http://open.mitchellhamline.edu/facsch/267 


\title{
Where Have all the Patent Lawyers Gone? Long Time Passing...
}

\begin{abstract}
This article pursues two distinct, but related hypotheses. First, as total LSAT takers decline, we expect to see a decline in the number of new attorneys admitted to the patent bar. Second, as the number of new patent attorneys shrinks and the number of women pursuing engineering degrees increases, we expect that the patent bar will become more female.

In order to test these hypotheses, we gathered and collated data from the Law School Admission Counsel (LSAC) regarding students taking the Law School Admissions Test (LSAT), the United States Patent and Trademark Office (USPTO), the Society of Women Engineers (SWE), and the American Bar Association (ABA). The data establishes that the first hypothesis is true, but the second one is false. That is, the number of new entrants to the patent bar will drop precipitously. By 2018, new entrants will number one half of what they were in 2008. However, the number of female patent attorneys compared to the number of male patent attorneys will not change in this same time period. That is, even though the patent bar will shrink, the patent bar will not become more female.
\end{abstract}

\section{Keywords}

legal profession, patent bar, patent bar eligible

\section{Disciplines}

Intellectual Property Law | Legal Profession 


\title{
Where Have All the Patent Lawyers Gone? Long Time Passing ...*
}

\author{
Ken Port, ${ }^{\dagger}$ Lucas Hjelle, ${ }^{\ddagger}$ and Molly Littman ${ }^{\S}$
}

\section{Contents}

$\begin{array}{ll}\text { I. Introduction } & 194\end{array}$

$\begin{array}{ll}\text { II. Context } & 194\end{array}$

III.Hypothesis One: As LSAT Takers Shrink, the Number of New Patent Attorneys Will Shrink 197

IV. Hypothesis Two: The Patent Bar Will Become More Female 199

$\begin{array}{ll}\text { V. Significance } & 202\end{array}$

VI.Education of Would-Be Patent Lawyers 203

VII. Patent Law Faculty 206

$\begin{array}{ll}\text { VIII. Methodology } & 209\end{array}$

$\begin{array}{lr}\text { IX. Conclusions } & 213\end{array}$

*The article title is a reference to "Where Have All the Flowers Gone?" written by Pete Seeger in 1955. Dubbed as one of America's top political songs ever, it also is a contemplation of death. Ian K. Smith, Top 20 Political Songs: Where Have All the Flowers Gone, New Statesman, (March 25, 2010), http:/ /www.newstatesman.com/music/2010/03/top-20-political-songs.

${ }^{\dagger}$ Professor of Law, William Mitchell College of Law. We are deeply indebted to Ms. Julie Ekkers, Assistant Dean of Admissions, William Mitchell College of Law, for her and her staff's valuable assistance in the collection of data for this piece.

${ }_{\ddagger}^{\ddagger}$ Patent Attorney, Schwegman, Lundberg and Woessner. We are especially indebted to Professor Saurabh Vishnubhakat from the Center for Innovation Policy at Duke Law School for his valuable research and scholarship on female patent attorneys and his willingness to cooperate in this study.

${ }^{\S}$ William Mitchell College of Law '16. Ms. Littman will be a summer associate at Gray Plant Mooty in 2015. The views expressed in this article are those of the authors. 


\section{Introduction}

This article pursues two distinct, but related hypotheses. First, as total LSAT takers decline, we expect to see a decline in the number of new attorneys admitted to the patent bar. Second, as the number of new patent attorneys shrinks and the number of women pursuing engineering degrees increases, we expect that the patent bar will become more female.

In order to test these hypotheses, we gathered and collated data from the Law School Admission Counsel (LSAC) regarding students taking the Law School Admissions Test (LSAT), the United States Patent and Trademark Office (USPTO), the Society of Women Engineers (SWE), and the American Bar Association (ABA). The data establishes that the first hypothesis is true, but the second one is false. That is, the number of new entrants to the patent bar will drop precipitously. By 2018, new entrants will number one half of what they were in 2008. However, the number of female patent attorneys compared to the number of male patent attorneys will not change in this same time period. That is, even though the patent bar will shrink, the patent bar will not become more female.

\section{Context}

In 2012, Congress passed the America Invents Act (AIA). It passed with astounding bipartisan ${ }^{1}$ support. $^{2}$ The AIA was perceived as a jobs bill. Even President Obama claimed that it would result in the creation of jobs. ${ }^{3}$ In the lead up to its passage, many claims were made that it would generate jobs in America, thereby leading to the bipartisan support. ${ }^{4}$ Many irrational claims were made that it would produce 200,000 or more jobs. ${ }^{5}$ It appeared that these jobs would come in the form of patent attorneys who would be needed to prosecute the increased number of patent applications that would need to be filed because the AIA would spur innovation. ${ }^{6}$

In fact, there is no actual data on how many, if any, jobs the AIA will even-

\footnotetext{
${ }^{1}$ H.R. 1249 (112th): Leahy-Smith America Invents Act, GOvTRACK, https:/ / www.govtrack.us/congress/votes/ 112-2011/h491 (last visited Mar. 15, 2015) (71\% of all Congressional representatives voted in favor of the AIA).

${ }^{2}$ House Vote \#491 on June 23, 2011 passed with 304 Representatives voting yes, 117 voting no, and 10 not voting. See Final Vote Results for Roll Call 491, CLERK H.R., http://clerk.house.gov/evs/2006/roll491.xml (last visited Mar. 15, 2015). Senate Vote \#129 on September 8, 2011 passed with 89 Senators voting yes, 9 voting no, and 1 not voting. U.S. Senate Roll Call Votes $112^{\text {th }}$ Congress- $1^{\text {st }}$ Session, U.S. SENATE, http://www. senate.gov/legislative/LIS/roll_call_lists/roll_call_vote_cfm.cfm?\&congress $=112 \&$ session $=1 \&$ vote $=00129$ (last visited Mar. 15, 2015). The total number voting yes was 393 out of 519 and the percentage voting yes was $75.7 \%$.

${ }^{3}$ See Remarks by the President at Signing of the America Invents Act, White House (Sept. 16, 2011), http: //www.whitehouse.gov/the-press-office/2011/09/16/remarks-president-signing-america-invents-act.

${ }^{4}$ The America Invents Act: Promoting American Innovation, Creating American Jobs, Growing America's Economy, PATRICK LEAHY, http://www.leahy.senate.gov/imo/media/doc/SenateHouseComparison-OnePager. pdf (last visited May 3, 2015).

${ }^{5}$ David Goldman, Will Patent Reform Really Create 200,000 Jobs?, CNN MONEY (Sept. 16, 2011), http:/ /money. cnn.com/2011/09/08/technology/patent_reform_jobs/.

${ }^{6} I d$. ("The patent bill will create jobs-jobs for patent attorneys . . . .") (internal citation omitted).
} Id. 
tually create. To date, all such claims appear to be mere political hyperbole. ${ }^{7}$

If the AIA were to produce 200,000 patent attorney jobs as some have claimed, at current rates, it would take 200 years to realize this goal. Today, approximately 1,000 people a year enter the patent bar. Even if the claim of 200,000 new jobs were broadly applicable to any new employment, there is no evidence or data that suggests the AIA will be directly responsible for 200,000 new jobs in the foreseeable future. For example, one study that focused on startup companies was relied upon to suggest that every new patent would create between three and ten new jobs. ${ }^{8}$ With the expected increase in the number of patent applicants due exclusively to the AIA, this would imply that the AIA is to be responsible for generating between 20,000 and 66,667 new patents. ${ }^{9}$ However, even the authors of this principle study expressly cautioned against using their study for determining the number of jobs the AIA is expected to produce. Therefore, the claim of the number of jobs that would be allegedly created by the AIA seems disingenuous. As will be demonstrated below, there will be an overwhelming amount of patents to file and prosecute, but that there appears to be no data to support the suggestion that the AIA is itself responsible for creating patent attorney jobs.

Also, even if the AIA is to produce jobs for patent attorneys in America, it appears that in the lead up to its passage and the subsequent implementation, no one talked to law schools or did anything to encourage potential law students to attend law school and become a patent attorney. ${ }^{10}$

Inventors seem to have received the message. New filings for patent applications continue to rise, as shown in Graph 1 below. ${ }^{11}$ Once again, there is no statistical correlation between the AIA and an increase in patent application filings. As Graph 1 makes clear, the filings are increasing, but at a rate consistent with the constant rate prior to 2012, the effective date of the AIA. There has been no substantial increase in patent application filing as a result of the AIA. There is, and remains, a constant year-to-year steady increase in new patent application filings.

\footnotetext{
${ }^{7}$ See Brad Plumer, Everything You Need to Know About Patent Reform in One Post, WASH. POST (Sept. 6, 2011), http://www.washingtonpost.com/blogs/wonkblog/post/ everything-you-need-to-know-about-patent-reform-in-one-post/2011/09/06/gIQAOD4V7J_blog.html (reporting that Senator Leahy's office is unsure where this 200,000 number came from).

${ }^{8}$ See Robert Merges, et al., Guest Post: What We Said (and Didn't Say) in the Berkeley Patent Study, PAtentlyO (Aug. 5, 2011), http://patentlyo.com/patent/2011/08/ guest-post-what-we-said-and-didnt-say-in-the-berkeley-patent-study.html. For the original study, see Stuart J.H. Graham, et al., High Technology Entrepreneurs and the Patent System: Results of the 2008 Berkeley Patent Survey, 24 BERK. TECH. L.J. 1255 (2009), available at http://www.btlj.org/data/articles/24_feature.pdf.

${ }^{9}$ The authors of the original study, Robert Merges, Pam Samuelson, and Ted Sichelman, later cautioned against any such calculation, stating "it is impossible solely from our data to draw conclusions about the general role of patents on innovation or jobs," and that "there is no principled way to determine from our data whether or not additional patents lead to additional jobs, much less the number of jobs created by each patent." Merges, supra note 8.

${ }^{10}$ For a summarized timeline of the passing of the AIA, see Manus Cooney, The America Invents Act-How It All Went Down, IP WATChDOG (Sept. 20, 2011), http://www.ipwatchdog.com/2011/09/20/ the-america-invents-act-how-it-all-went-down/id=19294/.

${ }^{11}$ See Patent Technology Monitoring Team, U.S. Patent Statistics Chart Calendar Years 1963-2013, USPTO, http://www.uspto.gov/web/offices/ac/ido/oeip/taf/us_stat.htm (last modified July 24, 2014). In 1963, 66,715 utility patent applications of US origin were filed. In 2013 , there were 287,831 . The total number of patents filed in 2013 was 609,052. Id.
} 


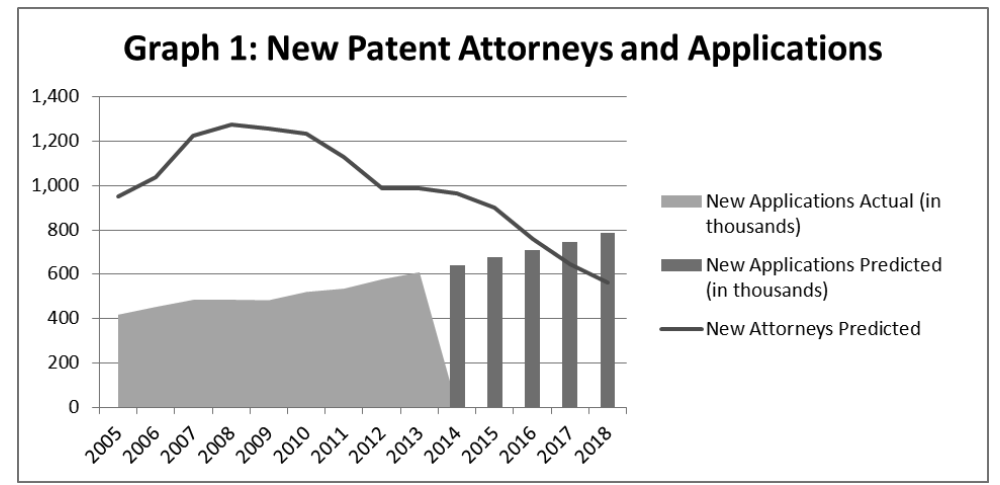

That is, the number of patent applications has increased and will continue to increase, ${ }^{12}$ AIA or not. Inventors and patent attorneys seem to all have been made are aware of the AIA. ${ }^{13}$ However, the number of new patent attorneys entering the patent bar is about to fall precipitously, and no one is taking notice. Contrary to our hypothesis, women are not making inroads in the proportion of patent attorneys in the United States. Approximately $30 \%$ of patent attorneys are female and that will remain unchanged. ${ }^{14}$ Women patent attorneys are not making up for the dramatic decrease in new patent attorneys.

Furthermore, we are often told that the number of jobs requiring a juris doctor degree is shrinking drastically and that potential law students have received this message and have stopped attending law school. ${ }^{15}$ Accepting, for the sake of argument that this is true, were normal market forces in play, one would expect to see a flood of patent bar eligible students attending law school as there are many jobs for such qualified candidates. ${ }^{16}$ Hiring in patent firms is robust, ${ }^{17}$ however, this has not translated into more patent bar eligible students attending law school. In fact, the decrease of patent bar eligible students far exceeds the decrease of non-patent bar eligible law students. ${ }^{18}$

\footnotetext{
${ }^{12}$ The number of applications is projected to grow by 5\% each year. See USPTO, FISCAL YEAR 2015 PRESIDENT'S BUdGET: THE USPTO CONGRESSIONAL BUDGET JUSTIFICATION 14 (Mar. 13, 2014), available at http://www.uspto.gov/about/stratplan/budget/fy15pbr.pdf.

${ }^{13}$ The USPTO has released several press releases regarding the AIA. For an example, see Richard Maulsby, President Obama Signs America Invents Act, INVENTORS EYE (OCT. 2011), http://www.uspto.gov/inventors/ independent/eye/201110/americainventsact.jsp.

${ }^{14}$ See Graph 6, infra at 201.

${ }^{15}$ See Elizabeth Olson \& David Segal, A Steep Slide in Law School Enrollment Accelerates, NY Times (Dec. 17, 2014), http://dealbook.nytimes.com/2014/12/17/law-school-enrollment-falls-to-lowest-level-since-1987/? r=1; Ethan Bronner, Law Schools' Applications Fall as Costs Rise and Jobs Are Cut, NY TimEs (Jan. 30, 2013), http:// www.nytimes.com/2013/01/31/education/law-schools-applications-fall-as-costs-rise-and-jobs-are-cut.html.

${ }^{16}$ Courtney Rubin, Spark Your Legal Career With These In-Demand Law Jobs, U.S. NEWS \& WORLD REP. EDUC., http://www.usnews.com/education/best-graduate-schools/top-law-schools/articles/2014/ 03/12/spark-your-legal-career-with-these-in-demand-law-jobs (Mar. 12, 2014) ("Intellectual property law is an area where firms are always hiring associates."). See also Rich Steeves, Intellectual Property Law Jobs on the Rise, INSIDE COUNSEL (Nov. 12, 2013), http://www.insidecounsel.com/2013/11/12/ intellectual-property-law-jobs-on-the-rise.

${ }^{17}$ See Rubin, supra note 16.

${ }^{18}$ See Law School Admissions Council \& American Bar Association, Applicants Majors Summary (document on file with author). For example, in 2000, 232 mechanical engineering students enrolled in law school, while 8,893
} 
Not only is misrepresenting the AIA as a jobs bill misleading at best, but there will soon be a shortage of new patent attorneys to do the very work the AIA encourages. New patent applications are projected to increase at $5 \%$ a year for the next 4 years and the number of new patent attorneys will fall by $50 \%$ in the next 4 years (compared to 2008). ${ }^{19}$ This is a crisis and policymakers and educators need to take action now.

\section{Hypothesis One: As LSAT Takers Shrink, the Number of New Patent Attorneys Will Shrink}

Our first hypothesis was that as the number of total LSAT takers decreased, the number of new admissions to the patent bar would correspondingly decrease. The data supports this conclusion, but also shows that the number of new admissions to the patent bar will decrease at a rate far faster than the decrease in all LSAT takers. Over the last 5 years, approximately 1,200 new patent attorneys received registration numbers each year. ${ }^{20}$ Within 5 years, the number of new entrants to the patent bar will decrease substantially. By 2018, the number of new entrants to the patent bar is expected to shrink to approximately 600 new patent attorneys per year, less than half of what it is today. ${ }^{21}$ The 1,200 entrants to the patent bar in 2008 is a documented number. ${ }^{22}$ The estimation of only 600 entrants in 2018, however, is likely optimistic. That is, there are predicted to be 600 people eligible to take the patent bar in 2018 . However, not every patent bar eligible student becomes a patent attorney. Although the percentage of patent bar eligible individuals who enter the patent bar has increased in the last decade, today, approximately $20 \%$ of patent bar eligible individuals will choose not to become patent attorneys. That is, the projection of 600 new patent attorneys in 2018 needs to be adjusted by the likelihood that at least some of those eligible candidates will not become patent attorneys.

We know the number of new patent attorneys will shrink by looking at indicators. First, the number of LSAT takers who are patent bar eligible are dropping precipitously. ${ }^{23}$ In 2008-09, 5,408 people who possessed patent bar presumptive eligible degrees took the LSAT. ${ }^{24}$ By 2012-13, that number became 2,474 LSAT takers, which is a drop of $46 \% .{ }^{25}$ Within the patent bar-eligible

political science students enrolled. In 2013, 9,715 political science students enrolled in law school, while only 116 mechanical engineering students enrolled. $I d$.

${ }^{19}$ See Graph 1, supra at 196.

${ }^{20}$ See Graphs 2 and 3. These values represent the number of patent attorneys who have passed the patent bar and have been issued registration numbers. Note that the total number of people passing the patent bar includes attorneys and agents, which can be seen in Graph 2 and in the table at Exam Results By Fiscal Year, USPTO, http://www.uspto.gov/ip/boards/oed/exam/past/results/ (last visited May 3, 2015).

${ }^{21}$ See Graph 3.

${ }^{22}$ Exam Results By Fiscal Year, supra note 20; see also Graph 3.

${ }^{23}$ Law School Admissions Council \& American Bar Association, Applicants Majors Summary (document on file with author).

${ }^{24}$ Port, Hjelle \& Littman, LSAT Patent Bar Eligible Majors (document on file with author).

${ }^{25} \mathrm{Id}$. 
range of LSAT takers, the most employable people as patent attorneys are Mechanical Engineers, Electrical Engineers, Computer Engineers, and Chemical Engineers. The data supports this by showing that most patent attorneys fit within one of these four fields. ${ }^{26}$ The number of law students with these degrees has declined even more steeply than the general population of all LSAT takers with patent bar presumptive eligible degrees over this same time period. ${ }^{27}$ In 2008-09, the total number of people who took the LSAT (patenteligible and not patent-eligible) was $84,119 .{ }^{28}$ Similarly, by $2012-13$, that number had become 59,354 , which is a drop of $29 \% .^{29}$

In the last decade, the number of new patent agents has increased somewhat. However, as shown in Graph 2 below, this amount is not nearly enough to alleviate the burden that patent attorneys are about to realize. ${ }^{30}$

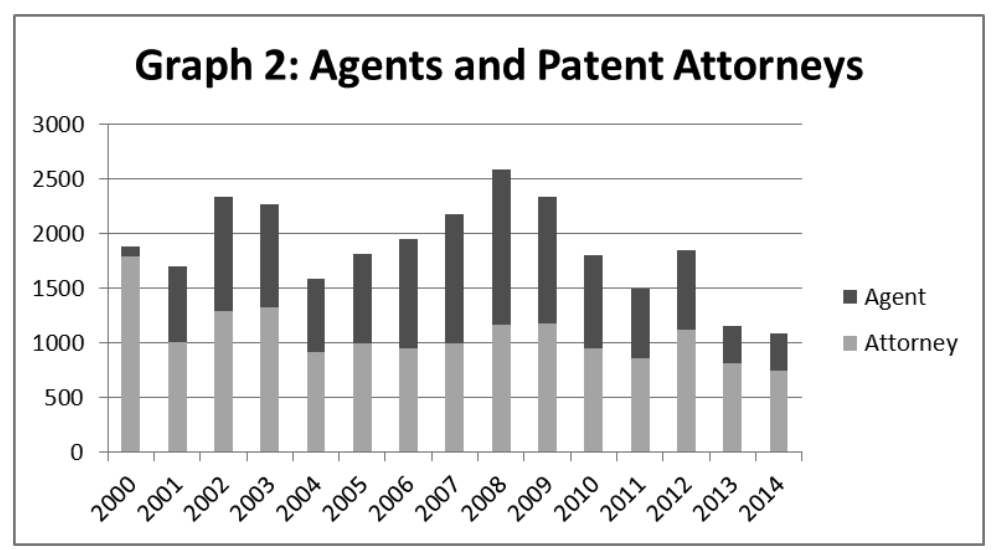

The ratio of registered patent attorneys to patent bar eligible students entering ABA accredited law schools has remained fairly consistent at about 31.5\% over the years. ${ }^{31}$ Graph 3 below shows the predictive ability of this $31.5 \%$ assumption for the decade spanning 2004-2013, the predicted totals for 2014, and the predicted number of new registered patent attorneys in 2015-2017.

\footnotetext{
${ }^{26}$ See id.; see also Bloomberg News, New Law Creates a Demand for Patent Specialists, NY TIMES (Oct. 9, 2011), http://www.nytimes.com/2011/10/10/business/new-law-creates-demand-for-patent-specialists.html ("The most highly sought degrees held by patent lawyers are in electrical engineering, computer science and computer engineering.").

${ }^{27}$ Mechanical Engineers (ME): 378/181/52\%; Electrical Engineers (EE): 452/184/59\%; Computer Engineers (Comp. E): 130/49/62\%; Chemical Engineers (Chem E): 199/115/62\%. Key: LSAT takers possessing this degree in 2010/LSAT takers possessing this degree in 2014/percent decline in four years. See Port, Hjelle \& Littman, supra note 24 .

${ }^{28}$ See Law School Admissions Council \& American Bar Association, Applicants Majors Summary (document on file with author).

${ }^{29}$ See id.

${ }^{30}$ See Graph 2, infra at 6.

${ }^{31}$ See ABA to Patent Attorney Spreadsheet, infra at 19.
} 


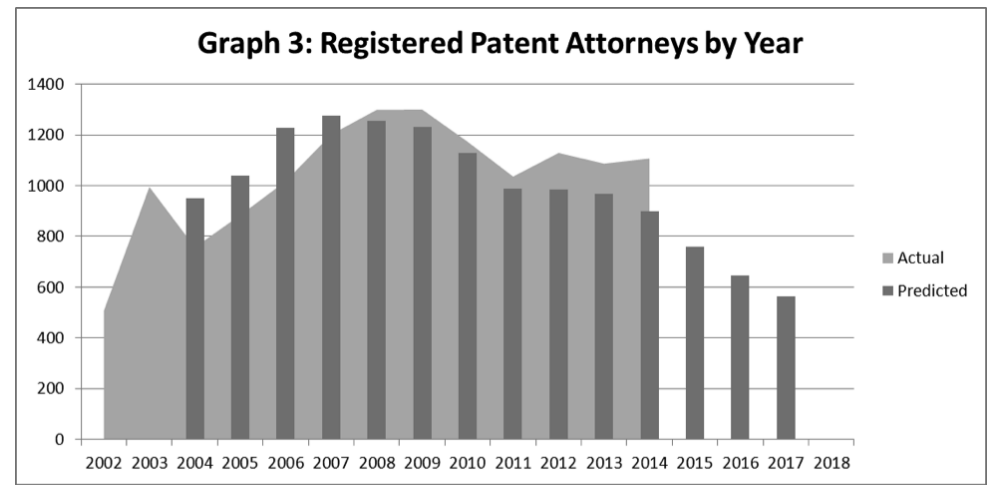

It is also interesting to examine how this assumption predicts the increased workload per patent attorney. Using the $31.5 \%$ prediction, Graph 4 was generated to show predicted ratio of new applications filed per new patent attorney. ${ }^{32}$ As with Graph 3 above, actual data matches well with predicted data. As can be seen below, the predictive ability of the $31.5 \%$ is consistent for years 2005-2014, and the trend shows the ratio of new applications filed per new patent attorney to double between 2014 and 2018.

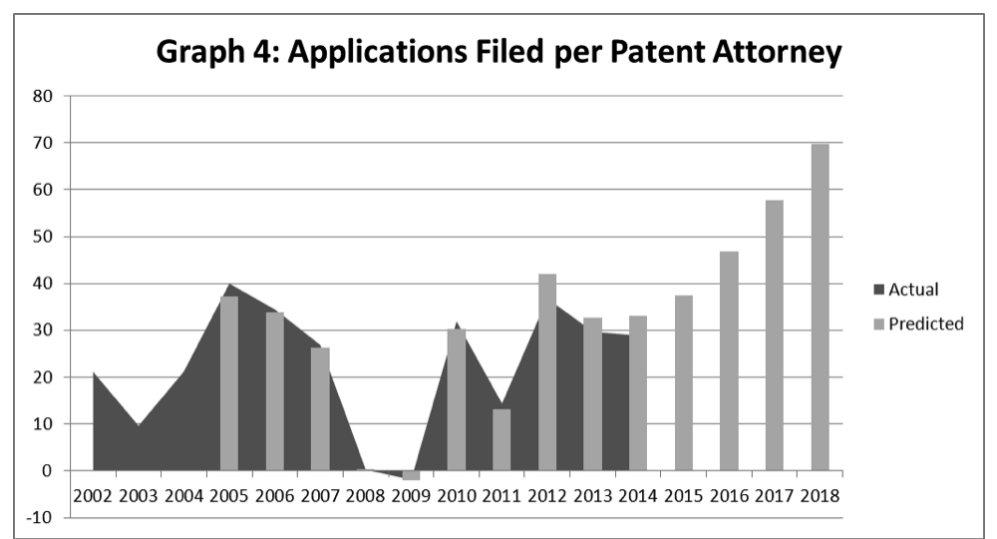

\section{Hypothesis Two: The Patent Bar Will Become More Female}

As the total number of LSAT takers decreased and the number of female engineers increased, ${ }^{33}$ we expected the patent bar to become more female. Our data supports the opposite. The ratio of male to female patent attorneys has

\footnotetext{
${ }^{32}$ See Graph 4.

${ }^{33}$ In 2009 , women obtained $17.8 \%$ of engineering bachelor's degrees. In 2013, that number rose to $19.1 \%$. See Michael T. Gibbons, Engineering by the Numbers 12 (2009), available at http://www.asee.org/ papers-and-publications/publications/college-profiles/2009-profile-engineering-statistics.pdf; BRIAN L. YO-
} 
not changed significantly in the last 25 years. As such, we have no data to support the hypothesis that there will be an increase in the proportion of females in the patent bar.

In addition, the claims of an increased number of women in engineering appear to be an exaggeration. Only $19.1 \%$ of engineering degrees granted in 2013 were to women. ${ }^{34}$ Comparatively, women make up nearly $30 \%$ of all registered patent attorneys. ${ }^{35}$

Contrary to the precipitous fall in the total number of patent attorneys, the percentage of female patent attorneys will remain unchanged, as shown in Graph 5 below. The overall student population at some law schools is now in excess of $60 \%$ female. ${ }^{36}$ This is an increasing trend since 1950, but the increase in the last 40 years is significantly greater, as shown in Graph 6 below. ${ }^{37}$ However, while the number of female patent bar eligible students have similarly increased, it is not enough to change the ratio of female to male patent attorneys or overcome the decline in patent bar eligible attorneys.

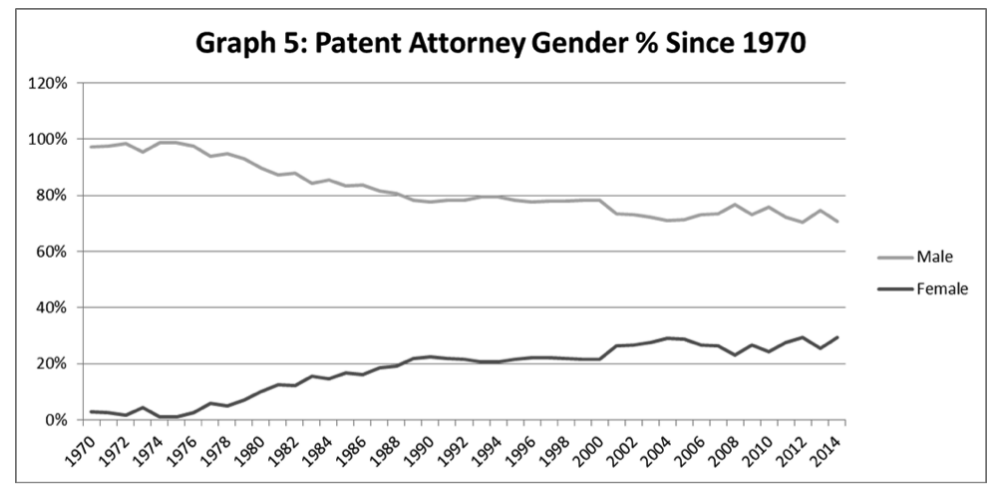

More importantly, those female patent bar eligible students and patent attorneys newly admitted to the patent bar do not necessarily possess those

DER, ENGINEERING BY THE NUMBERS 12 (2013), available at http://www.asee.org/papers-and-publications/ publications /14_11-47.pdf [hereinafter YODER 2013].

${ }^{34}$ See YODER 2013, supra note 33.

${ }^{35}$ See Graph 5.

${ }^{36}$ William Mitchell College of Law (WMCL) is 60\% female. See Student Profile, WM MitchelL, http: //web.wmitchell.edu/admissions/student-profile/ (last visited Mar. 15, 2015). While WMCL may have a higher percentage of women enrolled in the J.D. program, it is not much higher than the rest of the country. In general, women make up 47\% of J.D. students. See A.B.A. COMM'N ON WOMEN IN THE PROfESSION, A CURRENT GLANCE AT WOMEN IN THE LAW (2014), available at http://www.americanbar.org/content/dam/aba/ marketing/women/current_glance_statistics_july2014.authcheckdam.pdf.

${ }^{37}$ In 1970 , only $8.6 \%$ of J.D. candidates were women. In 1993, 50.4\% of students enrolled in a J.D. program were women. In 1994, that percentage dropped to $43.1 \%$. Since then, we have seen a steady increase in the number of women enrolled in J.D. programs. Currently, $47 \%$ of students enrolled in a J.D. program are women. See First YeAr And TOtal J.D. EnROllment by Gender, A.B.A. (2011), available at http://www.americanbar.org/content/dam/aba/administrative/legal_education_and_admissions_to_the_ bar/statistics/jd_enrollment_1yr_total_gender.authcheckdam.pdf. 


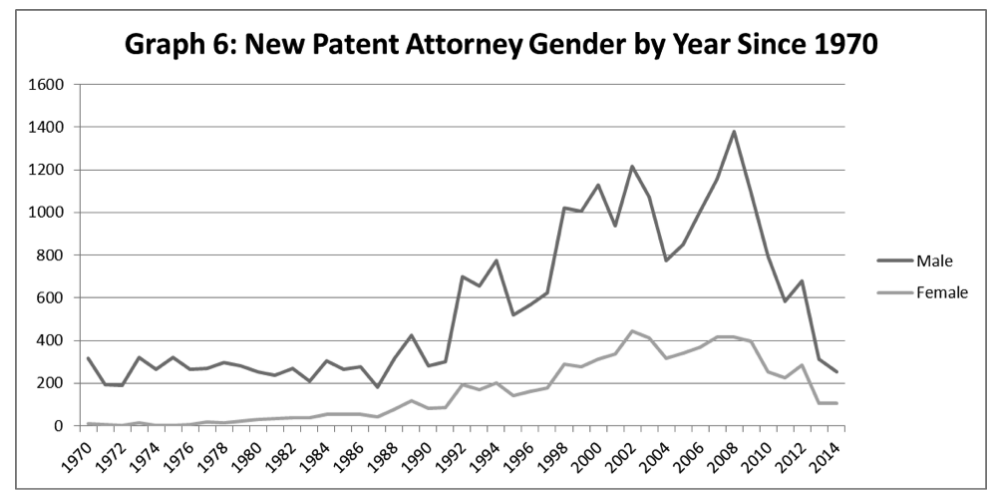

most marketable degrees for the patent law industry: mechanical, electrical, computer, and chemical engineering. In fact, the most popular engineering degrees earned by females are environmental engineering (45.8\%), biomedical $(38.9 \%)$, and chemical engineering $(32.3 \%) .{ }^{38}$ The least popular among women are computer engineering $(10.7 \%)$, mining engineering $(12.1 \%)$, and electrical engineering (12.3\%). ${ }^{39}$ Women who are obtaining STEM degrees are unlikely to affect the patent bar significantly because they are obtaining less "marketable" degrees, and because their degrees are not automatically eligible for admission into the patent bar. ${ }^{40}$

Interestingly, women have made significant inroads in related fields, such as the number of professors of patent bar eligible subject matters. For women, the most popular subjects to teach match very well with areas where there is high growth predicted for patent attorneys, including mechanical, electrical, computer, and chemical engineering. ${ }^{41}$ However, this fact has not demonstratively translated into more women pursuing those subjects, or into more

\footnotetext{
${ }^{38}$ YODER 2013, supra note 33, at 12. Since 2009, the percentage of women pursuing environmental engineering degrees has increased from $43.7 \%$ to $45.8 \%$, while biomedical saw a spike in 2012 at $39.2 \%$, and chemical engineering has seen a slow decline since 2009. In 2009, 35.9\% of women in engineering received chemical engineering degrees, while today that number is $32.3 \%$. However, chemical engineering is still one of the top three engineering majors for women today. See GIBBONS, supra note 33, at 12; BRIAN L. YODER, ENGINEERING BY THE NUMBERS 12 (2012), available at http:/ /www.asee.org/papers-and-publications/publications/11-47.pdf [hereinafter YODER 2012]; YODER 2013, supra note 33, at 12.

${ }^{39}$ See YODER 2013, supra note 33, at 12. While computer engineering is still among the least sought engineering degrees for women, there has been an increase in the percentage of women seeking computer engineering degrees. In 2009 , only $7.9 \%$ of women in engineering sought computer engineering degrees, while today that number is $10.7 \%$. Two degrees often sought after by patent law firms, electrical and mechanical engineering, are also on the low end of the scale for women seeking engineering degrees. In 2013, only $12.5 \%$ of women in engineering sought mechanical engineering degrees and only $12.3 \%$ of women in engineering sought electrical engineering degrees. See GIBBONS, supra note 33, at 12; YODER 2013, supra note 33, at 12.

${ }^{40}$ Environmental Engineering is not listed as an automatically qualifying degree for the patent bar, nor is it mentioned as qualifying coursework. However, an environmental engineering student may qualify if she has taken enough coursework in physics, biology, chemistry, or other science or engineering. For a list of patent bar eligible majors and requirements, see Do I Qualify to Sit for the Patent Bar Exam? [hereinafter Eligible Majors], PATBAR, http:/ / patbar.com/uspto-patent-bar-exam-requirements.shtml (last visited May 4, 2015).

${ }^{41}$ While the percentage of women teaching in these disciplines has increased, the composition of tenure-track professors teaching in the fields of mechanical, computer, chemical, and electrical engineering remains predominately male. Female tenure-track professors are more likely to teach in the areas of environmental and biomedical engineering, as well as engineering management. See Port, Hjelle \& Littman, Data on Women and Engineering Majors (document on file with author).
} 
women subsequently entering the patent bar. Additional study would be needed to determine why having female professors for the most important (by employment statistics) patent bar-eligible subjects does not translate into more women entering those fields. Theories that support affirmative action would suggest the opposite. ${ }^{42}$ That is, we are told that our teachers need to look more like the students in order to encourage and support those students. Professors of color are more likely to encourage, support, and attract students of color. ${ }^{43}$ However, based upon the data in this study, female electrical engineering professors, for example, are not attracting female students to electrical engineering.

\section{Significance}

The number of patent attorneys will fall and the field will remain a distinctively male endeavor. Policy makers may want to respond to these findings. The drop in new patent attorneys following the AIA may create an ideal environment for women to enter an otherwise predominantly male field. Policy makers may take early advantage of this opportunity, such as by encouraging more females not only to go to science and engineering schools, but also to become specific types of engineers, which would then enable them to be more employable as patent attorneys.

The AIA policy planning is deficient in that it encourages patenting on one hand, yet does nothing to reverse the trend of declining patent bar entrants on the other. There will have to be a national, concerted effort to change this trend if the AIA's alleged lofty goal of creating jobs is to be realized.

There are many possible ways to either incentivize mechanical, electrical, computer, and chemical engineering graduates to become patent attorneys; however, it may be time to change the nature of the patent bar. As discussed below, the United States is alone in the world in making patent attorneys such

\footnotetext{
${ }^{42}$ Sapna Cheryan, et al., Do Female and Male Role Models Who Embody STEM Stereotypes Hinder Women's Anticipated Success in STEM?, Social Psychology \& Personality Sci. (2011), available at http:/ / depts.washington.edu/sibl/Publications/Cheryan\%20Siy\%20et $\% 20$ al.\%20Role\%20Models\% 20SPPS\%20in\%20press.pdf(suggesting that women entering STEM fields may be less concerned with gender than whether their role models embody STEM stereotypes). Comparatively, studies show that women role models play a role in introducing women to STEM fields. See e.g., Penelope Lockwood, "Someone Like Me Can Be Successful": Do College Students Need Same-Gender Role Models?, 30 Psychology Women Q. 36, 44 (2006) ("In sum, female role models may be especially beneficial for women for a variety of reasons," including: "inspirational examples of success . . ; possibil[ity of] overcoming traditional gender barriers . . ; serv[ing] as . . guides to the potential accomplishments for which other woman can strive . . .; [and] demonstrating competence in traditionally male occupations ....").

${ }^{43}$ E.g., Ana Maria Villegas, et al., Closing the Racial/Ethnic Gap Between Students of Color and Their Teachers: An Elusive Goal, Equity \& ExCELlENCE IN EduC., 283, 285-88 (2012), available at http://www.montclair. edu/profilepages/media/439/user/Villegas-Strom-Lucas--2012-EEE.pdf (explaining that this role model theory "emphasizes the role that teachers of color can play in bolstering the sense of worth of students of color, motivating them to strive for academic success, and encouraging them to envision professional careers for themselves."). It may be that the lack of minority professors in the STEM fields is not limited to gender. One source argues that racial minorities also lack role models in the STEM fields. See Kelsey Sheehy, Minorities Need STEM Role Models Too, U.S. NEWS \& WORLD REP. (June 28, 2012), available at http://www.usnews.com/news/blogs/ stem-education/2012/06/28/minorities-need-stem-role-models-too.
} 
a reified class of people. ${ }^{44}$ It may be time to end the requirement that patent attorneys possess specific undergraduate degrees to be patent bar eligible. Perhaps the patent bar should be opened up to any person possessing a juris doctor degree or, even more radically, to anyone who can pass the patent bar, regardless of their undergraduate educational background. ${ }^{45}$

\section{Education of Would-Be Patent Lawyers}

In the United States, the PTO has authority to regulate all patent attorneys. ${ }^{46}$ As such, it has determined that all patent attorneys must possess one of several technical degrees in science or engineering, or otherwise prove their competency to a sufficient extent so as to be allowed by the PTO to enter the coveted "patent bar." ${ }^{47}$ The United States is anomalous in this regard. Other industrialized nations, like Japan, allow anyone to sit for their nation's patent bar. ${ }^{48}$ In the United States, only people who possess a science or engineering undergraduate degree, or the equivalent are allowed to work as a patent attorney and only patent attorneys (or agents) who are registered to practice through the patent bar can file patent applications on behalf of a third party client.

In addition, all those admitted to the patent bar who wish to be patent attorneys must also graduate from an accredited American law school and pass a state bar exam. ${ }^{49}$ Only when a person passes both a state bar exam and the patent bar exam may that person then represent himself or herself as a "patent attorney." 50

In many other countries the title of "patent attorney" is not such a reified entity. Many countries are much more liberal in deciding who can file patent applications and who cannot. In Japan, for example, a person with the title of "patent attorney" (benrishi 弁理士) is not necessarily also a regular attorney with a legal education or admitted to practice law in Japan. ${ }^{51}$ In Japan, a per-

\footnotetext{
${ }^{44}$ See infra Part VI.

${ }^{45}$ For a discussion of whether a technical degree requirement is needed and/or valid, see Nicholas Matich, Patent Office Practice After the America Invents Act, 23 FED. CIR. B.J. 225, 241-44 (2013).

${ }^{46} 35$ U.S.C. § 2(b)(2)(D) (2014) ("The Office . . may govern the recognition and conduct of . . attorneys . . . $. ")$.

${ }^{47}$ Eligible Majors, supra note 40.

${ }^{48}$ In Japan, any person who has passed the patent attorney examination is qualified to be an attorney. Further, any person who has been an examiner at the Japan Patent Office for seven years or more, and has completed the requisite practical training, can become a patent attorney. See Patent Attorney Act, Act No. 49 of 2000, ch. 1 art. 7 (Japan) [hereinafter Japan Patent Attorney Act], available at http://www.jpaa.or.jp/english/aboutus/pdf/ PatentAttorneyAct.pdf.

${ }^{49} 37$ C.F.R. $§ 11.8$ ("An individual seeking registration as an attorney under $\S 11.6(a)$ must provide a certificate of good standing of the bar of the highest court of a State that is no more than six months old.").

${ }^{50}$ AM. B. Assoc. R. 7.4 "Communication of Fields of Practice \& Specialization" allows an individual to designate themselves as a "patent attorney" only if the individual is a "lawyer admitted to engage in patent practice before the United States Patent and Trademark Office ...." Id.

${ }^{51}$ See Japan Patent Attorney Act, supra note 48; Training at the German and Patent and Trade Mark Office: Opportunities for School Leavers and University Graduates, DEUTSCHES PATENT-UND MARKENAMT, http://www. dpma.de/english/the_office/training/index.html (last visited Mar. 15, 2015) [hereinafter Training at German PTO] (requiring only "a university degree in a science, engineering or technical subject and a subsequent almost three-year training under supervision of a patent attorney and at the patent authorities. After the training the candidates must pass a written and oral qualifying examination.").
} 
son becomes a patent attorney by taking and passing the respective patent bar exam. ${ }^{52}$ Patent attorneys and lawyers are two separate classifications of law providers. Therefore, it is common in Japan to have people admitted to the patent bar who would be ineligible to be patent attorneys in the United States because they do not possess a JD or its equivalent. In the United States, patent attorneys are a particular class of individuals with heightened requirements; they must possess one of a limited number of science or engineering degrees and also be admitted to a State Bar before being called a patent attorney.

In 1836, the United States patent system changed from a registration-based system to one of examination, ${ }^{53}$ making it more difficult for inventors to obtain patents. ${ }^{54}$ Where inventors previously filed their own patent applications, inventors began to hire experts in the minutia of drafting applications and convincing the newly created Patent Office that it should recognize the invention as novel. ${ }^{55}$ Historically, attorneys did not practice patent prosecution because inventors favored those with a background in science over those with formal legal training. ${ }^{56}$

It was not until the end of the nineteenth century that attorneys began prosecuting patents. ${ }^{57}$ While attorneys were entering the patent field, there was no official requirement that an attorney must be the one to file a patent application. Therefore, "patent agents" - those with a technical background, but no legal training-were able to file patent applications on behalf of inventors. ${ }^{58}$ These agents were not subject to any professional code of conduct and sometimes were known to swindle inventors. ${ }^{59}$ In 1899 , regulations were placed on those who could practice patent prosecution. ${ }^{60}$ However, because the bar failed to convince Congress and the Patent Office to rid the practice of nonlawyers, ${ }^{61}$ anyone with the requisite scientific background or experience could sit for the patent bar, regardless of whether they had formal legal training. ${ }^{62}$

The result is that the United States has created a special classification of

\footnotetext{
${ }^{52}$ See Japan Patent Attorney Act, supra note 48, ch. 2; Training at German PTO, supra note 51.

${ }^{53}$ See Patent Act of 1836, ch. 347, 5 Stat. 117, available at http://patentlyo.com/media/docs/2008/03/Patent Act_of_1836.pdf; William I. Wyman, The Patent Act of 1836, 1 J. PAT. OfF. SOC'Y 203, 207 (1919) ("The law restored the examination method of granting patents, established the Patent Office as a distinct and separate bureau, placed it in charge of a chief to be called the Commissioner of Patents, and provided a complete organization to make effective the American plan of predetermining the validity of the invention before the grant.").

${ }^{54}$ See Patent Act of 1836, supra note 53 (requiring that the patent application for a new invention or discovery include a written description of the invention in such a manner as to educate another person skilled in the particular art on how to make and use the invention). These new requirements were more strenuous than under the Patent Act of 1793, in which practically anyone who accurately filed a patent application was issued a patent. In the early years under the Patent Act of 1836, the rejection rate was $75 \%$. See also Kara W. Swanson, The Emergence of the Professional Patent Practitioner, IRIS 519, 524, 526 (2009), available at http:/ /ipbio.org/pdfs/ papers/fulltext\%20(1).pdf.

${ }^{55}$ Christ J. Guerrini, The Decline of the Patent Registration Exam, 91 NEB. L. REv. 325, 332 (2012).

${ }^{56} \mathrm{Id}$.

${ }^{57}$ James Willard Hurt, The Growth of the American LaW: The LaW MaKers 297-98 (1950).

${ }^{58}$ Naomi R. Lamoreaux \& Kenneth L. Sokoloff, Intermediaries in the U.S. Market for Technology, in FINANCE, INTERMEDIARIES, AND ECONOMIC DEVELOPMENT 209, 211 (Stanley L. Engerman et al. eds., 2003).

${ }^{59}$ See Sperry v. Fla., 373 U.S. 379, 390 (1963).

${ }^{60} I d$.

${ }^{61}$ Guerrini, supra note 55 at 334.

${ }^{62}$ See 37 C.F.R. § 11.7; see also Elligible Majors, supra note 40.
} 
attorneys who are permitted to do patent work. ${ }^{63}$ It is only these attorneys that can communicate with the USPTO on behalf of a third party client. Patent agents and patent attorneys can handle any matter that comes up before the USPTO in the prosecution of a patent. However, patent agents are strictly prohibited from the practice of law, even regarding other matters relating to the patents. For example, only a patent attorney may draft documents dealing with interferences or draft opinion letters regarding whether one patent is likely to infringe another. ${ }^{64}$

Historically, individuals who desired to become patent attorneys graduated from law school and then sat for the patent bar as well as a state bar examination. In the mid-1990s, law schools began educating students to become patent attorneys or "intellectual property" experts of varying degrees. Ranking organizations began scoring law schools on the reputation of their "IP Programs." In the early 1990s, unlike today, it was unusual for a law school to have one person who primarily taught patent law.

There is some reliable data on the topic of patent law offerings at American Law Schools. In 2004, Port commenced the Mitchell Study on IP Curricula. ${ }^{65}$ In that year, there were 139 schools that offered a patent law course. ${ }^{66}$ By 2011, the 212 ABA accredited law schools offered an average of eight IP courses at each school. ${ }^{67}$ It is now no longer unusual to have many full-time professors dedicated to teaching IP courses. In fact, of the 212 law schools in the United States, 155 offered at least one three credit, stand-alone patent course in $2011 .^{68}$ Thirty-one of these schools offered patent law as a multi-semester, sequenced class and awarded 6-8 credits for this sequence. ${ }^{69}$

In under 20 years, IP generally and patent law specifically have gone from a course of study that was rarely offered to a subject matter that is present, to one extent or another, in nearly every law school in America. In 2011, only five American law schools did not list any IP courses in their course catalogues. Today, some law schools offer 20 or more IP courses every year and at least

\footnotetext{
${ }^{63}$ For the argument that the technical background requirement of patent attorneys no longer makes sense and the scope of subject matters accepted should be greatly expanded, see Corey B. Blake, Note: Ghost of the Past: Does the USPTO's Scientific and Technical Background Requirement Still Make Sense?, 82 TEX. L. REV. 735, 757-63 (2004).

${ }^{64}$ Patent agents may provide patentability opinions, but only for opinions that do not involve the practice of law. The example given for an allowable opinion: "In contrast, a validity opinion issued in contemplation of filing a request for reexamination would be in contemplation of a proceeding before the Office involving a patent. Due

to registration to practice before the Office in patent cases, a practitioner may issue a validity opinion in contemplation of filing a request for reexamination." Changes to Representation of Others Before the United States Patent and Trademark Office, 73 Fed. Reg. 47650 (Aug. 14, 2008), available at http://www.uspto.gov/ sites/default/files/web/offices/com/sol/notices/73fr47650.pdf; see Sperry v. Fla., 373 U.S. 379 (1963).

${ }^{65}$ Mitchell Study on IP Curriculum 2007, WM MiTCHELL, http://web.wmitchell.edu/intellectual-property/ mitchell-report-on-intellectual-property-curricula-2007/ (last visited Mar. 15, 2015) [hereinafter Curriculum Study 2007]. See Kenneth L. Port, Intellectual Property Curricula in the United States, 46 IDEA 165 (2005).

${ }^{66}$ See Curriculum Study 2007, supra note 65.

${ }^{67}$ See Mitchell Study on IP Curriculum 2011, WM MiTCHELL, http:/ / web.wmitchell.edu/intellectual-property/ mitchell-report-on-intellectual-property-curricula/\%20 (last visited Mar. 15, 2015) [hereinafter Curriculum Study 2011].

${ }^{68} \mathrm{Id}$.

${ }^{69} \mathrm{Id}$.
} 
one law school claims that it offers upwards of 40 courses a year. ${ }^{70}$ Regardless of whether this is a legitimate claim or marketing puffery, IP has become so hot that some law schools claim that every course that touches on IP, be it first-year Property Law or Anti-trust Law, Sports Law, Entertainment Law or Cyberlaw, etc., is an IP course. ${ }^{71}$ Truly, in 20 years' time, patent law has gone from an extreme outlier in law school curricula to a mainstay and focal point. This much is self-evident.

There have been scholars who have pointed out that the trend of always expanding patent rights was not sustainable, ${ }^{72}$ but their focus has always been on the appropriate scope of IP rights, not on whether there would be enough professionals to do the job. Most American law schools rushed to create IP courses focused on training an entire new generation of patent lawyers. When students graduate from law school today, it is not unusual for them to have taken six or more courses which focused on various aspects of patent law and to have already sat for and passed the patent bar exam.

\section{Patent Law Faculty}

By some estimates, ${ }^{73}$ in 1999, there were only 56 law schools in the United States that offered a course titled "patent law." Unfortunately, these estimates were based upon a survey of IP professors in America at that time. ${ }^{74}$ As there is a danger that IP professors may over-report or under-report the number of courses their law school offers, and there is no way to check the veracity of these claims, the estimates are not particularly reliable as an accurate data set. However, they at least can provide a helpful starting point. Since it is impossible to roll back the clock 20 years to study what patent law education looked like at that point in time, they will have to suffice.

For the assertion that IP generally, and patent law specifically, has increased in significance in the law school setting in the last 20 years, Professor Kwall's study seems applicable and relevant. As stated above, in 2011, there were 155 law schools that offered a three-credit, standalone course on patent law. ${ }^{75}$ In the academic year of 2014-15, 144 schools offered a standalone patent course. ${ }^{76}$

\footnotetext{
${ }^{70}$ DePaul University Law School's Center for Intellectual Property law and Information Technology claims that they offer "more than 40" IP classes. See Curriculum, DePaul College OF LaW, http://law.depaul. edu/about/centers-and-institutes/center-for-intellectual-property-law-and-information-technology/Pages/ curriculum.aspx (last visited Mar. 15, 2015).

${ }^{71}$ For the list of 31 "Patent Law Certificate" courses that DePaul University Law School offers, see http://www.depaul.edu/university-catalog/degree-requirements/law/law-jd/certificate-requirements/ Pages/intellectual-property-patent-law-certificate.aspx.

${ }^{72}$ See, e.g., Martin J. Adelman \& Sonia Baldia, Prospects and Limits of the Patent Provision in the TRIPS Agreement: The Case of India, 29 VAND J. TRANSNAT'L L. 507 (1996).

${ }^{73}$ Roberta Rosenthal Kwall, The Intellectual Property Curriculum: Findings of Professor and Practitioner Surveys, 49 J. Legal EduC. 203, 203 (1999). Starting in 2005, I have kept a longitudinal record of course offerings in United States law schools. See Kenneth L. Port, Intellectual Property Curricula in the United States, 46 IDEA 165 (2005); Curriculum Study 2011, supra note 67.

${ }^{74} \mathrm{~K}$ wall conducted a nationwide survey of law professors. She received responses from 69 schools (sometimes from more than one professor at a school). See Kwall, supra note 73, at 203-04.

${ }^{75}$ See Curriculum Study 2011, supra note 67.

${ }^{76}$ See Curriculum Study 2014 (document on file with author).
} 
Of those 144 schools, 95 were taught by full-time, tenured or tenure-track faculty, and 46 were taught by adjunct faculty. ${ }^{77}$

IP programs appear to be focusing primarily upon patent law. Twenty years ago, it was rare for a patent attorney to become a full-time law professor. Today, if a law school does not employ at least one patent attorney, its IP program may be considered deficient in some regard. In fact, today, many law schools take the most pride in the writings of professors who teach patent law and who are admitted to the patent bar. Until the decline in general law school enrollment began, there was keen competition for the best talent among patent attorney professors. It has become commonly accepted in the field that the "best talent" is defined as those writing the most conceptual scholarship regarding patent law and those who were admitted to the patent bar or who are at least patent bar eligible. ${ }^{78}$

There are 49 schools claiming in their online literature in 2014 to have the equivalent of an "institute" for IP within their law school. ${ }^{79}$ Of these 49 schools, 35 schools employ at least one professor who is admitted or eligible to be admitted to the patent bar and who taught patent law in the 2014-15 school year.

In addition, Expresso lists 63 journals as publishing exclusively or primarily intellectual property related articles. ${ }^{80}$ Twenty years ago there were 21 such journals. ${ }^{81}$

The teachers of patent law courses often were previously adjunct professors and full-time patent attorneys. It used to be very rare for a full-time professor to teach a patent law course because they simply did not exist. ${ }^{82}$ Today, some of the most theoretical publications are written by patent professors who have joined the ranks of academia in the last 20 years and are admitted to the patent bar or are patent bar eligible.

Twenty years ago, the career trajectory of some current patent professors

\footnotetext{
${ }^{77}$ Some courses are co-taught by a professor and adjunct. We counted both the professor and adjunct when the course is co-taught. Of the full-time faculty, 66 were admitted to the patent bar or eligible to be admitted to the patent bar. Of the adjunct faculty, 45 were admitted to the patent bar or eligible to be admitted to the patent bar. See Curriculum Study 2014, supra note 76.

${ }^{78}$ For example, George Washington School of Law lists three co-directors of their program and 14 faculty members. See Faculty, GEO. WASH. L., http://www.law.gwu.edu/Academics/FocusAreas/IP/Pages/Faculty. aspx (last visited Feb. 4, 2015). At least four of these 17 people who seem to be involved with GW's IP program are admitted to or are eligible to be admitted to the patent bar. Id.

${ }^{79}$ Curriculum Study 2014, supra note 76.

${ }^{80}$ Select Law Reviews, BEPRESS, http://law.bepress.com/do/expresso/submit/select (last visited Mar. 15, 2015).

${ }^{81}$ See Law Journals 20 Years (document on file with author). Of the 63 existing IP law reviews, 21 are on volume 20 or higher. Presumably, each law review can be counted by the number of volumes it publishes and this directly corresponds to the number of years of its existence. For example, a law review working on Volume 4 would mean that the law review has been in existence for 4 years.

${ }^{82}$ For example, the AALS Directory of Law Teachers from 1998-99 lists only 222 professors of intellectual property in the United States. By 2011-12, that same publication lists over 870. See Directory of LAW TEACHERS, AALS (2014).
} 
was unthinkable. People like Dan Burk, ${ }^{83}$ Mark Lemley, ${ }^{84}$ and Scott Kieff ${ }^{85}$ largely were absent from the list of professors in the United States. Many of these patent law professors have excelled from entry-level assistant professorships without tenure to tenured full professors and even to decanal roles and appointments. ${ }^{86}$ Although there are some senior faculty who are patent attorneys, such as Martin Adelman, ${ }^{87}$ this was an extremely rare situation only 20 years ago. In fact, Don Chisum, the author or Chisum on Patents, ${ }^{88}$ the leading treatise in this field since $1978,{ }^{89}$ is not admitted to the patent bar. ${ }^{90}$ Edmund Kitch $^{91}$ and Harvey Perlman, ${ }^{92}$ the authors of one of the first textbooks on intellectual property law in America, ${ }^{93}$ are not admitted to the patent bar, nor are they patent bar eligible.

In 2011-12, the American Association of Law Schools reported that there are now some 870 professors of intellectual property in the United States. ${ }^{94}$ The 1998-99 version of the same directory lists 222 intellectual property law professors. ${ }^{95}$ A basic count of the number of full-time faculty teaching an in-

\footnotetext{
${ }^{83}$ For a biography, see Dan L. Burk, U.C. IRVINE, http:/ / www.law.uci.edu/faculty/full-time/burk/ (last visited Mar. 15, 2015). Professor Burk started his professorial career at Seton Hall. He moved from Seton Hall to the University of Minnesota. From Minnesota, he moved to the University of California-Irvine to become an associate dean in the formation of a new law school. He is now the Chancellor's Professor of Law.

${ }^{84}$ For a biography, see Mark A. Lemley, STAN. L. SCH., https://www.law.stanford.edu/profile/mark-a-lemley (last visited Mar. 15, 2015). Professor Lemley started his professorial career at the University of Texas Law School. From Texas, he moved to Boalt Hall School of Law at the University of California at Berkeley. He is currently the director of the Stanford University program in Law, Science \& Technology and the William H. Neukom Professor of Law.

${ }^{85}$ For a biography, see F. Scott Kieff, GEO. WASH. UNIV. L., http://www.law.gwu.edu/Faculty/profile.aspx? $\mathrm{id}=16061$ (last visited Mar. 15, 2015) which states in relevant part as follows: "Professor Kieff joined the faculty at the George Washington University Law School in the summer of 2009, after serving on the faculty at Washington University in Saint Louis, where he was a Professor in the School of Law with a secondary appointment in the School of Medicine's Department of Neurological Surgery. He was named Fred C. Stevenson Research Professor at the George Washington University Law School in the fall of 2012. He took a leave of absence from George Washington University effective October 18, 2013, to swear in as a Commissioner of the U.S. International Trade Commission, having been nominated to that post by President Barack H. Obama, recommended unanimously by the U.S. Senate's Committee on Finance, and confirmed by unanimous consent of the Senate on August 1, 2013, for the term expiring on June 16, 2020."

${ }^{86}$ See e.g., Dan L. Burk, supra note 83.

${ }^{87}$ For biography, see Martin J. Adelman, GEO. WASH. UNIV. L. http://www.law.gwu.edu/faculty/profile. aspx?id=1701 (last visited Mar. 15, 2015).

${ }^{88}$ For curriculum vitae [hereinafter Chisum CV], see http:/ /www.chisum-patent-academy.com/wp-content/ uploads/Chisumcv-March-2014.pdf.

${ }^{89}$ See Chisum on Patents, LeXISNeXIS STORE, http://www.lexisnexis.com/store/catalog/booktemplate/ productdetail.jsp?pageName=relatedProducts\&prodId=10111 (last visited Mar. 15, 2015) (“Chisum on Patents is also the most cited treatise in patent law today- cited more than 800 times by the U.S. federal courts, twice as much as the nearest competitor since it was released in October 1978.").

${ }^{90}$ See Chisum CV, supra note 88.

${ }^{91}$ For biography, see Edmund W. Kitch, UNIV. VA. L. SCH. http://www.law.virginia.edu/lawweb/faculty. nsf/FHPbI/1180712 (last visited Mar. 15, 2015)

${ }^{92}$ For biography, see, Harvey Perlman, UnIV. NeB. LinCOLN, http://www.unl.edu/chancellor/bio.shtml (last visited Mar. 15, 2015).

${ }^{93}$ Edmund W. Kitch \& Harvey S. Perlman, Legal Regulation of the Competitive Process: Cases, Ma-

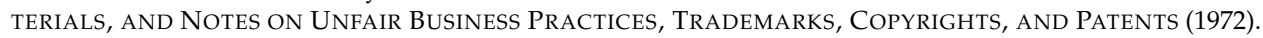

${ }^{94}$ THE AALS DiRECTORY OF LAW TEACHERS 2011-2012. These are professors that self-report that they teach a course on intellectual property. There is no indication of the frequency of that course and no verification that they actually do teach a course in intellectual property.

${ }^{95}$ The AALS DiReCTORY OF LAW TEACHERS 1998-99.
} 
troduction to patent law course has now reached $95 .{ }^{96}$ All of these full-time faculty are either tenured or tenure-track professors. Therefore, they are incentivized to write and place their articles in as high a ranked law review as is possible. Twenty years ago, law reviews shied away from publishing IP articles. Today, not only have IP law reviews proliferated, but many non-IP focused law reviews regularly publish IP topics.

That is, by hiring and employing 95 faculty members to teach patent law, we have given them a great incentive to write academic literature. While this is a positive development, it does not explain whether demand for the education provided by patent professors had preceded or has succeeded their employment. If student demand is the driver of all such engines and that student demand is dropping, it would seem that the demand curve for patent professors should also be dropping.

\section{Methodology}

Various data sets and analyses have been used throughout this article. Below is a brief description of the data gathering and analysis methodology for the count of currently registered patent attorneys, a predictive estimation of patent attorneys as predicted by ABA-admitted student data, an estimation of attorney gender, and a count and predictive estimate of new patent applications.

Patent Bar registration number data has been collected primarily from the USPTO website, which offers a freely downloadable current list of active registration numbers for patent attorneys and patent agents. However, the date of registration corresponding to each registered patent attorney or agent is only available by accessing a person-specific webpage, so a script was generated to download each of these person-specific pages and aggregate the data. ${ }^{97}$ Additional data for registration numbers of patent attorneys and agents no longer practicing was collected from various sources, including PatentBuddy.com.

Most of the dates corresponding to each registration number are provided by the USPTO data. Registrants that have a date for both attorney and agent often represent individuals who have passed the patent bar before passing the state bar and, upon passing the state bar, updated their status from patent agent to patent attorney. Because all patent attorneys have passed their respective state bar, these individuals are counted as patent attorneys and not counted as patent agents.

The predictive estimation of patent attorneys has been generated by extrapolating ABA-admitted student data. The ABA provided data for students

\footnotetext{
${ }^{96}$ Curriculum Study 2014, supra note 76.

${ }^{97}$ The entire list of registered attorneys and agents is available in CSV format at https://oedci.uspto.gov/ OEDCI/index.jsp. The web page for each registered attorney or agent is available by using their registration number within a generalized URL, such as the author's page at https://oedci.uspto.gov/OEDCI/details.do? regisNum $=72945$. Some registration numbers do not have an associated attorney or agent, so a list of all available URLs was generated using the registration numbers downloaded from the PTO CSV file. This list of URLs was then used as the input of a call to the program "wget" to download each page; for example, as "wget -nocheck-certificate -i./reg_numbers_temp.txt-w $0.5-\mathrm{O} . /$ reg_dates_temp.txt." (Here, the "-w" wait flag was used to slow the process to reduce the likelihood that this download would be erroneously flagged as a "denial of service" cyber-attack.)
} 
admitted to ABA-approved schools, where the admitted students were separated by undergraduate major. As a prerequisite for taking the Patent Bar, the PTO provides a General Requirements Bulletin for Admission to the Examination, which includes a list of eligible undergraduate majors. ${ }^{98}$ These majors were used to filter the ABA-approved students, and a number of patent bar eligible students was determined for each of the years 2000-2011. Because the time between admission, graduation, and taking the patent bar may vary for each individual, the number of new ABA-admitted students was compared against the number of new patent attorneys for each year. Because most law schools require three years of coursework, a ratio of ABA-admitted students to new patent attorneys for each year was calculated for delays ranging from 3 years to 5 years, as can be seen in Table 1:

Table 1: ABA to Patent Attorney Spreadsheet

\begin{tabular}{|c|c|c|c|c|}
\cline { 2 - 5 } \multicolumn{1}{c|}{} & 3 Years & 4 Years & 5 Years & Average \\
\hline 2000 & \multicolumn{4}{|c}{} \\
2001 & \multicolumn{4}{|c}{} \\
2002 & & & & \\
2003 & $33.0 \%$ & & $33.0 \%$ \\
2004 & $23.0 \%$ & $25.1 \%$ & & $24.0 \%$ \\
2005 & $22.7 \%$ & $26.8 \%$ & $29.3 \%$ & $26.3 \%$ \\
2006 & $25.1 \%$ & $26.1 \%$ & $30.9 \%$ & $27.4 \%$ \\
2007 & $30.2 \%$ & $29.7 \%$ & $30.9 \%$ & $30.2 \%$ \\
2008 & $33.2 \%$ & $32.6 \%$ & $32.1 \%$ & $32.6 \%$ \\
2009 & $36.3 \%$ & $33.2 \%$ & $32.6 \%$ & $34.1 \%$ \\
2010 & $37.4 \%$ & $32.8 \%$ & $30.0 \%$ & $33.4 \%$ \\
2011 & $33.1 \%$ & $33.0 \%$ & $29.0 \%$ & $31.7 \%$ \\
2012 & $36.8 \%$ & $36.1 \%$ & $36.0 \%$ & $36.3 \%$ \\
2013 & $38.1 \%$ & $35.5 \%$ & $34.7 \%$ & $36.1 \%$ \\
\hline Mean & $31.7 \%$ & $31.1 \%$ & $31.7 \%$ & $31.5 \%$ \\
\hline Std. Dev. & $5.7 \%$ & $3.9 \%$ & $2.4 \%$ & $4.0 \%$ \\
\hline
\end{tabular}

Averaging these delays resulted in an estimate that, for patent bar test delays from $\mathrm{ABA}$ admission ranging from 3 years to 5 years, an average of $31.5 \%$ of students admitted to ABA-approved law schools with patent bar eligible majors eventually become registered patent attorneys.

The $31.5 \%$ estimate matches actual numbers quite well. The graph below shows the predictive ability of this $31.5 \%$ assumption for the decade spanning 2004-2013, the predicted totals for 2014, and the predicted number of new registered patent attorneys in 2015-2017 as shown in Graph 3, reprinted below:

\footnotetext{
${ }^{98}$ Office of Enrollment and Discipline, General Requirements Bulletin for Admission to the Examination for Registration to Practice in Patent Cases before the United States Patent and Trademark Office, USPTO, available at http://www.uspto.gov/ip/boards/oed/exam/OED_GRB.pdf (last visited Feb. 4, 2015). The authors acknowledge that other "Bachelor's Degrees In Other Subjects" enables students with majors not listed to "establish to the satisfaction of the OED Director that he or she possesses the necessary scientific and technical training under either Category B or Category C below" (id. pp. 4-5), where Category B is also "Bachelor's Degree in Another Subject," and Category C includes "Practical Engineering or Scientific Experience."
} 


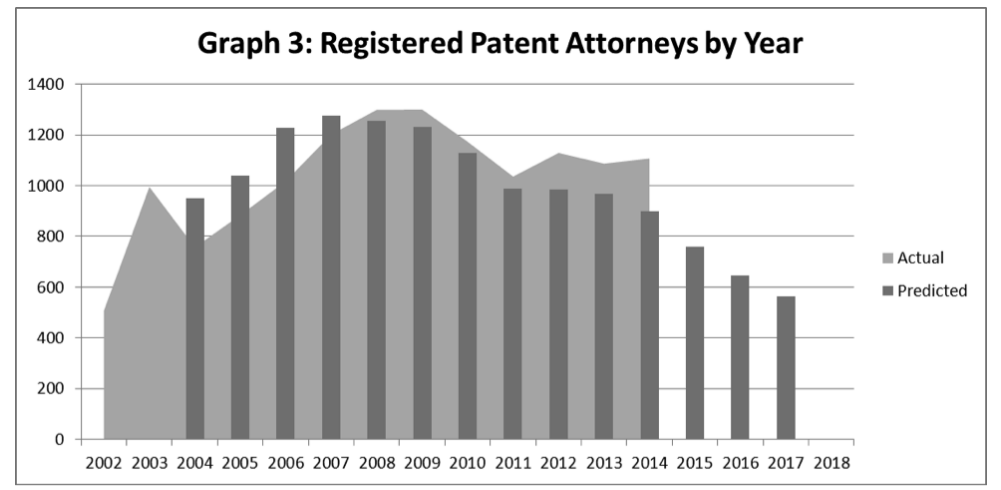

Data for patent attorney gender was not available through the PTO, so the estimation of patent attorney gender is primarily name-based. A spreadsheet was generated using the names of all of the registered patent attorneys, and duplicate names were removed. Similar to the systematic downloading of registration numbers, the de-duplicated list of all names was used to generate a URL, and the URL download was used to generate a spreadsheet of name, gender, and gender probability. This data set was generated using the website Genederize.io, which states the website "utilizes big datasets of information, from user profiles across major social networks and exposes this data through its API." ${ }^{\prime 99}$ Invocation of the API results in a text string, which includes an estimated gender, a probability of that gender, and a count of the number of names used to generate the probability. ${ }^{100}$ This textual gender information was transferred to a spreadsheet, and a lookup function was used to crosscheck the list of registered patent attorneys against names, generating an estimated gender for registered patent attorneys and agents. This data was used to produce gender-based graphs, such as the "Patent Attorney Gender \% Since 1970" graph in Section IV. This also provides interesting comparisons of new agents and new patent attorneys by gender, as shown in Graph 6, reprinted below:

The above graph shows a precipitous drop in the number of new patent attorneys in both genders from 2008. While this appears to be caused predominantly by a shortfall of patent eligible law students, this may be due in part to

\footnotetext{
${ }^{99}$ Determine Gender of a First Name, GENDERIZE.IO, http:/ / genderize.io/ (last visited on Mar. 15, 2015).

${ }^{100}$ For example, a request using the URL "http://api.genderize.io?name[0]=Aakash\&name[1]=Aakash\& name[2]=Aamer\&name[3]=Aaron\&name[4]=Aarti\&name[5]=Aasheesh\&name[6]=Aashish" results in an output that includes the following string:

\{“name":"Aakash", “gender":"male", "probability":" 1.00 ", “count": 16$\}$,

\{“name":"Aakash", "gender":"male"," probability":"1.00","count":16\},

\{“name":"Aamer","gender":"male"," probability":"1.00","count":5\},

\{“name":"Aaron", "gender":"“male", "probability":"0.99",,"count":1248\},

\{“name":"Aarti", “gender":" female", "probability":" 1.00 ","count":25\},

\{“name":"Aasheesh", "gender":null\},

(The string has been separated into bullets for purposes of this discussion.) As can be seen in the last bullet, there are names for which no gender estimate was provided; these names or genders were not used in the graphs or conclusions discussed herein.
} 


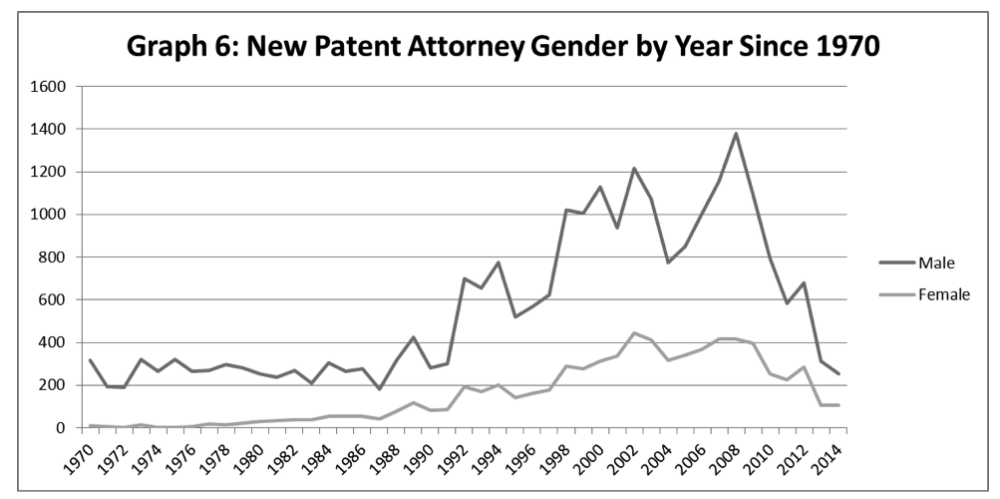

the possibility that some data for 2014 has not yet been made available. That is, the PTO publishes names of newly registered patent attorneys and patent agents every few weeks, and because the graph above is based only on an analysis of published names, part of the names in 2014 may not yet be available for inclusion in this figure. However, assuming there is no gender bias at the PTO, the ratio of male newly registered patent attorneys to female newly registered patent attorneys would not change, and the percentage of male to female in Section IV would not be expected to change significantly.

The count and predictive estimate of new patent applications is based on data conveniently compiled and provided by the USTPO. ${ }^{101}$ The data shows that patent filings since 2000 have increased an average of $5.3 \%$. Using this average increase, an estimated number of new patent filings was predicted for the years 2014 to 2018, as can be seen in Graph 7:

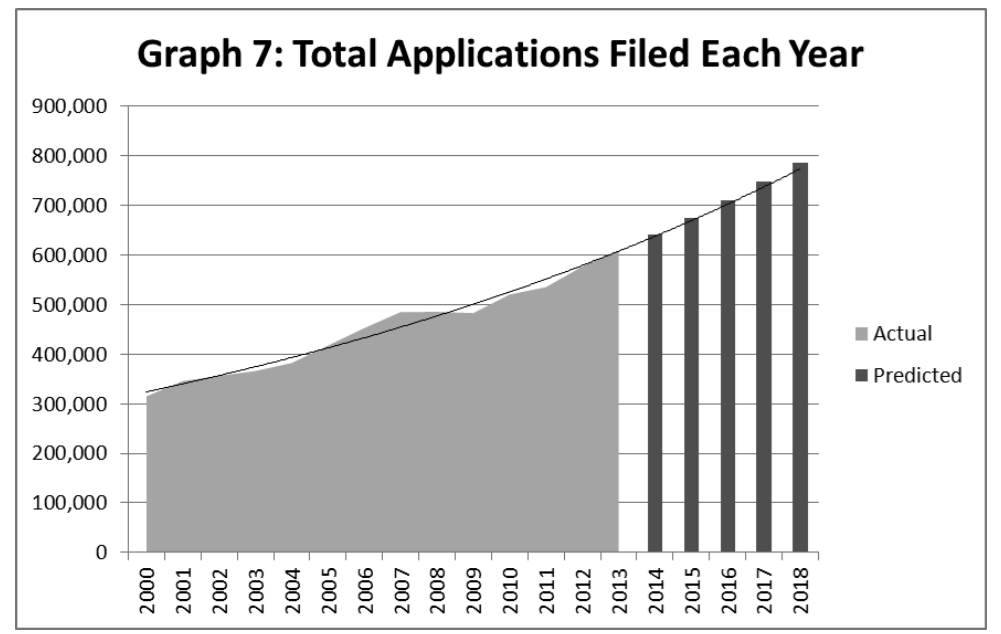

\footnotetext{
${ }^{101}$ Patent Technology Monitoring Team, Calendar Year Patent Statistics, USPTO, http:/ /www.uspto.gov/web/ offices/ac/ido/oeip/taf/reports.htm (last visited Mar. 15, 2015).
} 
This data was used to generate the graphs showing the predicted number of Applications Filed per Patent attorney and New Attorneys and Applications in Section II, above.

\section{Conclusions}

The number of new patent attorneys is dropping faster than the drop in total law school population. In fact, the number of new patent bar members will shrink to half of what it was in 2008 by 2018.

Even though far more women are now becoming engineers than ever before, they are not entering the patent bar. The ratio of women to men patent attorneys has remained relatively unchanged for 25 years and it will remain unchanged in the near future with patent law remaining a primarily male endeavor.

As the number of patent attorneys shrinks and the male to female ratio remains unchanged, policymakers and managers of patent firms need to take note. Productivity will have to increase significantly to keep up with demand. This increase in productivity will likely affect patent attorney retention. That is, as the number of patent attorneys drops, the billable hours for existing patent attorneys will assuredly increase. As billable hour requirements increase, more individuals will elect to exit, thereby exacerbating the problem. Coupled with the AIA's incentives to patent, patent law is about to face a crisis.

Another likely result of this finding is that as the number of patent attorneys shrinks, the fees that existing patent attorneys can charge for their services will increase. If this results, the precise converse of the intentions of the AIA will be realized. The AIA's incentives to patent will not be recognized and the PTO's statements regarding encouraging inventing will not be realized. 